\title{
Value chain analysis of sunflower in coastal areas of Amtali upazila of Barguna district
}

\author{
$\bowtie$ Mohammad Ismail Hossain, Shaon Afroz, Mahanambrota Das ${ }^{1}$, Md. Mojammel Haque ${ }^{2}$, \\ M. Serajul Islam ${ }^{3}$ and Lilly Lim-Camacho ${ }^{4}$
}

Department of Agribusiness and Marketing, Bangladesh Agricultural University, Mymensingh-2202, Bangladesh, ${ }^{1}$ Research and Advocacy Cell Head, Shushilan, Bangladesh, ${ }^{2}$ Graduate Training Institute, Bangladesh Agricultural University, Mymensingh2202, Bangladesh, ${ }^{3}$ Department of Agricultural Economics, Bangladesh Agricultural University, Mymensingh-2202 and ${ }^{4}$ Climate Smart Agriculture and Value Chain Analytics, Agriculture and Global Change, CSIRO Agriculture and Food, Australia

\begin{tabular}{l}
\hline ARTICLE INFO OPEN ${ }^{\text {Access }}$ \\
\hline Article history: \\
Received : 27 January 2019 \\
Accepted : 10 June 2019 \\
Published: 30 June 2019 \\
\hline
\end{tabular}

Keywords:

Marketing decision, value chain, stakeholders, sunflower, coastal areas

Correspondence:

Mohammad Ismail Hossain

凶: ismailho12@yahoo.co.in

\begin{abstract}
Sunflower is an important oil seed crop which is well fitted in Robi season of the coastal areas of Bangladesh. This study focused on sunflower value chain map, value addition, value chain governance and institutional linkages, and stakeholders and their roles and responsibilities in value adding process of sunflower. A total of 60 respondents were interviewed by using pretested questionnaire. A combination of purposive and snowball sampling techniques was used to select the respondents. Descriptive analytical technique was used to achieve the objectives. The study found that farmers were hardly engaged in sunflower marketing activities. The value chain map comprised of collectors/assemblers, processors, wholesalers and retailers. On an average, total costs (production and marketing) incurred by the farmers were Tk. 11,986.30/acre (100 decimals) of sunflower. Assemblers received a total gross margin of Tk. $588 / 100 \mathrm{~kg}$ of sunflower seeds. At wholesale node the total gross margin was found to be Tk. 209/100kg of sunflower seeds. It was observed that processor received gross margin of Tk. 878. The processors were the pivotal point for the sunflower oil in the study area. The findings revealed that $40 \%$ of the total sunflower seed productions were sold by farmers to chain actors in while the remaining $60 \%$ was left for own consumption. It was also found that there was certain arrangements of producers and traders in case of production and marketing of sunflower. The main business challenge in sunflower production is scarcity of quality seed and the marketing challenge is fluctuation of prices. Thus, policy should be guided to supply quality seeds and maintain the stable price of sunflower.
\end{abstract}

\section{Introduction}

Agriculture is the foundation of the economy of Bangladesh. It accounts for $14.10 \%$ of the sectorial share of GDP (BBS, 2018). Agriculture has linkages with the non-farm sector through forward linkages to agroprocessing, consumption and export; provides raw materials to industries and a market for manufactured goods. In order to improve the marketing arrangements for agricultural products, one needs to understand the channels that are currently used for trading in domestic and international markets. At present, the majority of small-scale agricultural producers are consuming their production to large extent within the household. The remaining surplus production can be sold either to the local markets or to national markets depending on the products and producer's access to the market. The main constraints for markets are inaccessible by marginal and small farmers due to low volume of production, poor road communication during the rainy season, and absence of well-functioning markets.
Sunflower is considered as an attractive crop because it is salt tolerant and has seemingly high yields, which in turn provide quick returns of the farmers. Sunflower is recently introduced as a good oil seed crop, potential source of high-quality edible oil and gaining popularity among local farmers because of its easy extraction method. Usually, when there is late rain or floods, sowing of oil seeds like mustard and sesame are deferred, hampering production. Under such conditions, sunflower stands as a good substitute to fill up this gap of production (Habib et al. 2017).

Sunflower is a short duration crop with a salinity threshold of approximately 2-12deciSiemens per meter $(\mathrm{dS} / \mathrm{m})$. The crop requires very little irrigation and relatively small amounts of fertilizers and insecticides, compared to sesame and mustard (Habib et al. 2017).

The sunflower oil industry also provides employment locally and offers opportunities for export and import substitution. The cake, that is a by-product of oil production, is high in protein and can be used as feed stock for poultry, small animals, dairy and draught animals which are used for ploughing and laddering the field.

\section{Cite this article}

Hossain, M.I., Afroz, S., Das, M., Haque, M.M., Islam, M.S. and Lim-Camacho, L. 2019. Value chain analysis of sunflower in coastal areas of Amtali upazila of Barguna district. Journal of Bangladesh Agricultural University, 17(1): 244-250. https://doi.org/10.3329/jbau.v17i2.41989 
A kilogram of sunflower seeds brings 500 to 600 grams of oil, an amount more than that of any other oil seeds. It is considered as premium oil as it contains around 66\% linoleic acid (unsaturated fatty acid) and its oil cake contains around $40-44 \%$ high quality protein (Habib et al., 2017). Therefore, it can be possible to boost up the production of edible oil by expanding sunflower growing area. Sunflower is competing with sesame and mustard. The area, production and yield under sunflower, mustard and sesame in Bangladesh are shown in Table 1. The consumption of edible oil in Bangladesh is around 1029 thousands MT in a year. Almost total demand of edible oil is fulfilled through import which spends a huge amount of foreign exchange. The values of imported edible oil and oilseeds were US\$ 1574 and US\$ 354 in 2017-18 (Bangladesh Bank, 2017). There are two oilseed crushing plants in Bangladesh have an estimated capacity of 4200 MT/day (Maximum 7000 MT/day) with the facility to crush soybean, mustard, rapeseed and sunflower (Gain Report, 2018).

Table 1. Oilseed area, production and yield in 2016-2017

\begin{tabular}{lcccc}
\hline Oilseeds & Area (acre) & Area (\%) & $\begin{array}{c}\text { Production } \\
(\mathrm{MT})\end{array}$ & $\begin{array}{c}\text { Yield } \\
\text { (T/acre) }\end{array}$ \\
Mustard & 831260 & 69.45 & 3662860 & 4.41 \\
Ground Nut & 91188 & 7.62 & 66060 & 0.72 \\
Linseed & 13257 & 1.11 & 4164 & 0.31 \\
Sesame & 92671 & 7.74 & 33999 & 0.37 \\
Soybean & 155351 & 12.98 & 96931 & 0.62 \\
Coconut & 9602 & 0.80 & 408635 & 42.56 \\
Sunflower & 3425 & 0.28 & 1913 & 0.56 \\
Total & 1196834 & 100 & 974552 & 7.869 \\
\hline
\end{tabular}

Source: BBS, 2017

The introduction of sunflower as a new crop in coastal area of Sekendarkhali and its nearby villages was based on the presence of local demand and the intervention of ACIAR projects, KGF, BARI and BRRI. However, there is inadequate understanding of its market, potentially putting farmers at risk. Analyzing the value chain of sunflower has the potential to identify opportunities to improve sunflower production and marketing, and assist farmers, industry stakeholders, project partners, and government agencies in the area to identify interventions to match these opportunities. In addition, value chain analysis has the potential to influence marketing decisions by the producers, processors, consumers, traders, investors, and others. This is achieved by identifying root causes for supply and marketing problems starting from production till the consumption of the product.

A value chain analysis describes all the activities which are included from the production to the consumption which included the primary producer, a processor (packaging, transforming of product etc.) and a retailer (Kaplinsky and Morris, 2001). In each of these links there is a process of value adding and these can be called value added links. These principles have been applied in the case of sunflower production in Bangladesh.

Most of the earlier studies in Bangladesh related to sunflower were conducted based on production and marketing. Khatun et al. (2016) and Rahman (2014) analysed profitability of sunflower; and Hossain et al. (2018) studied market dynamics of sunflower. A few studies such as ACT (2010), Mroto (2015), Larsson (2018) conducted abroad were on value chain analysis of sunflower. But these studies were not fully covered value chain analysis and governance of sunflower together. With this background, a study on the sunflower value chain gives insight about production, marketing and value adding activities which will be helpful for the farmers and other market actors for decision-making. Thus, this study focuses value chain analysis of sunflower to investigate the market dynamic, actors' roles and functions and production and marketing arrangements which will be helpful for policy makers as well.

\section{Methodology}

\section{Selection of the study area}

Sekendarkhali and its surrounding villages under Amtali Upazila of Barguna district were selected purposively for this study. Because in the selected areas farmers were introduced new crop (sunflower) as other crops are not produced due to salinity. Sekendarkhali village is located in Amtali Sadar Upazila of Sadar Union in Polder 43/1. Fig. 1 shows the village location and left side of the Figure (hand drawing) map the villagers during FGD.

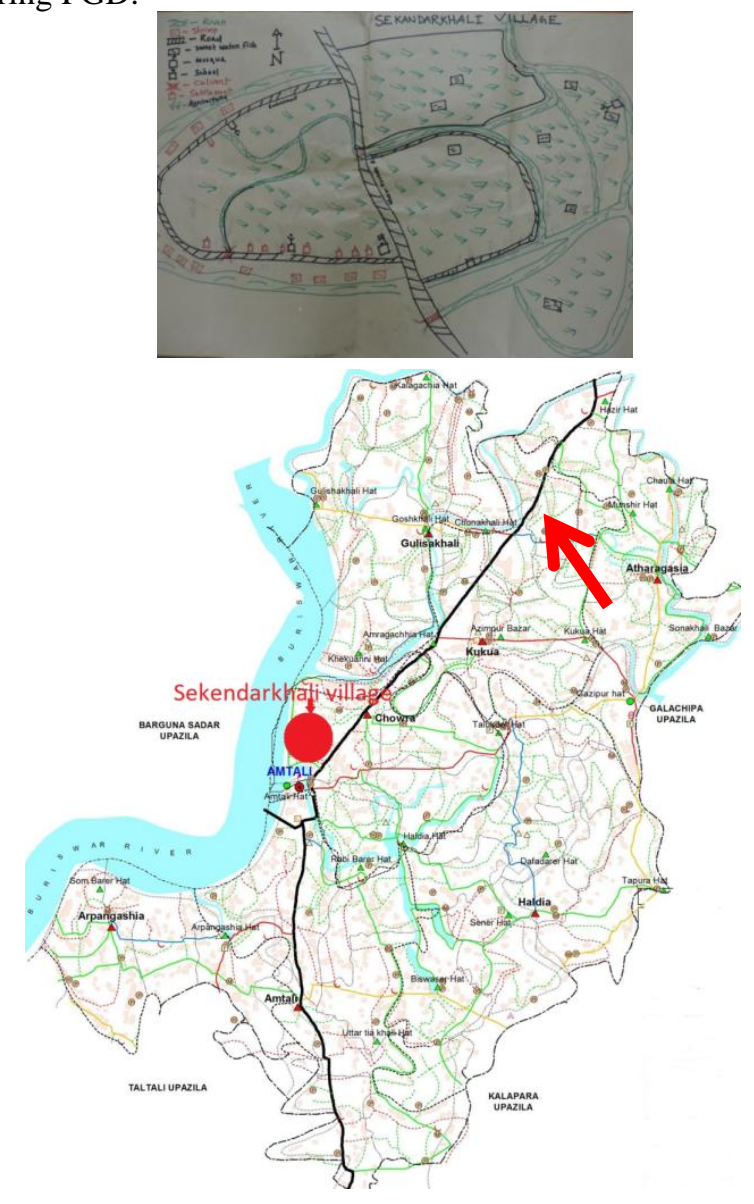


Fig. 1. Sekendarkhali village (Source: http://www.lged.gov.bd/UploadedDocument/Map/BARISAL/b arguna/amtali/amtali)

\section{Sample size}

Data were collected from farmers, assemblers/collectors, wholesalers, local processors and retailers. A combination of purposive and snowball sampling techniques was used to select the respondents. The sample size comprised of 60 respondents, where farmers were 20, assemblers/collectors/wholesalers were 12 , processors were 3 and remaining 25 were the retailers.

\section{Data collection methods}

The study used both qualitative and quantitative methods to collect the data. The collected data were validated with Shushilan (NGO who are working in the village) data. Both interview and survey techniques were used. The period of data collection was February to March 2018. Farmers and traders' data were collected through two separate types of questionnaire. Questions included farm type, crop choice, input use, cost of input and output, labour use, marketing activities, value addition and cost of value addition. Checklist was used during the FGD which is mainly focus on the broad questions and sequence of questions. Data were analysed through descriptive statistics. Data validation and triangulation were done through checking and rechecking the data.

At production level farmers were identified by physical visits to the sunflower fields. The information of where farmers were located was obtained from Shushilan, who operates in the area and is SIAGI's NGO partner in Bangladesh. Assemblers were identified by physical visits to the farmers at which transaction between farmers and assemblers took place. Wholesalers were identified by physical visits to the markets. Retailers were identified through physical visits to their marketing places.

\section{Results and Discussion}

\section{Role of actors in sunflower value chain}

Sunflower production in Sekendarkhali and its surrounding villages are predominantly done by small farmers with 0.01 to 1 acre of land. It was observed that about $90 \%$ of the farmers were small and marginal who owned on an average one acre of land. The process of sunflower farming included land preparation (ploughing), planting, regular weeding, and harvesting. While medium and large-scale farmers used tractors for ploughing, such service is only available for very few small and marginal farmers. In the production stage both women and men were involved, while its marketing was dominated by men with only $10 \%$ of women have brought sunflower seed into the markets as they were women managed farmers. Small and marginal sunflower farmers did not have any storage facilities and were interested to sell their seed soon after the harvest. As a result, the price of sunflower seed was low. Main inputs in sunflower production in Amtali were seeds and fertiliser and the cost of labour.

Production of good quality sunflower seeds was critical to production of good quality sunflower oil. Currently, the availability of good quality sunflower seeds represents the weakest link in the sunflower value chain in the regional market. In local markets, those farmers purchased sunflower seeds for planting, did not maintain quality certification which made problem of germination and yield. This was aggravated by the lack of standards in the existing marketing system of sunflower seeds in the central market. In addition, the annual supply of sunflower seeds in the closest city markets in Patuakhali and Dhaka fluctuates a lot. This was largely due to changes in weather conditions and seasonality of production.

The resulting unstable supply of sunflower seeds leads to capacity underutilisation in the sunflower oil milling industry. This affects the level of efficiency and effectiveness in the utilisation of investment in the sunflower value chain.

\section{Sunflower value chain map and dynamics}

The sunflower oil value chain is mapped in Fig. 2. The sunflower crop when harvested in most cases sold to local traders called collectors or assemblers either at the farmgate or at the local markets. These traders were either on commission from local processors or were acting independently. The independent traders may then locate buyers for the seeds, or negotiate with the processors, while the commissioned collectors usually work based on an order from the processor. In a small number of cases, some of the farmers also took their seed to the processors themselves and produced oil for themselves or sold sunflower oil in the local markets.

The processors were the pivotal point for the sunflower oil in the study area, as all the seed must passed through these actors and change the form. There were local mills that process sunflower seeds into oil who charged fees for processing. There is a big processor named Aamrato, located in the Patuakhali sadar, upazila that converts seed into oil and sells to the central market. The company agents collect seeds from the farmers of Sekendarkhali and surrounding villages. They therefore come into contact with a wide variety of actors and have different types of transactions.

On the other hand, smaller, local processors were paid for their milling services, and oil and cake are returned to the trader or farmer who brought it. In other cases, a processor may be purchased seeds and produced oil through processing and sold them to the other actors. 


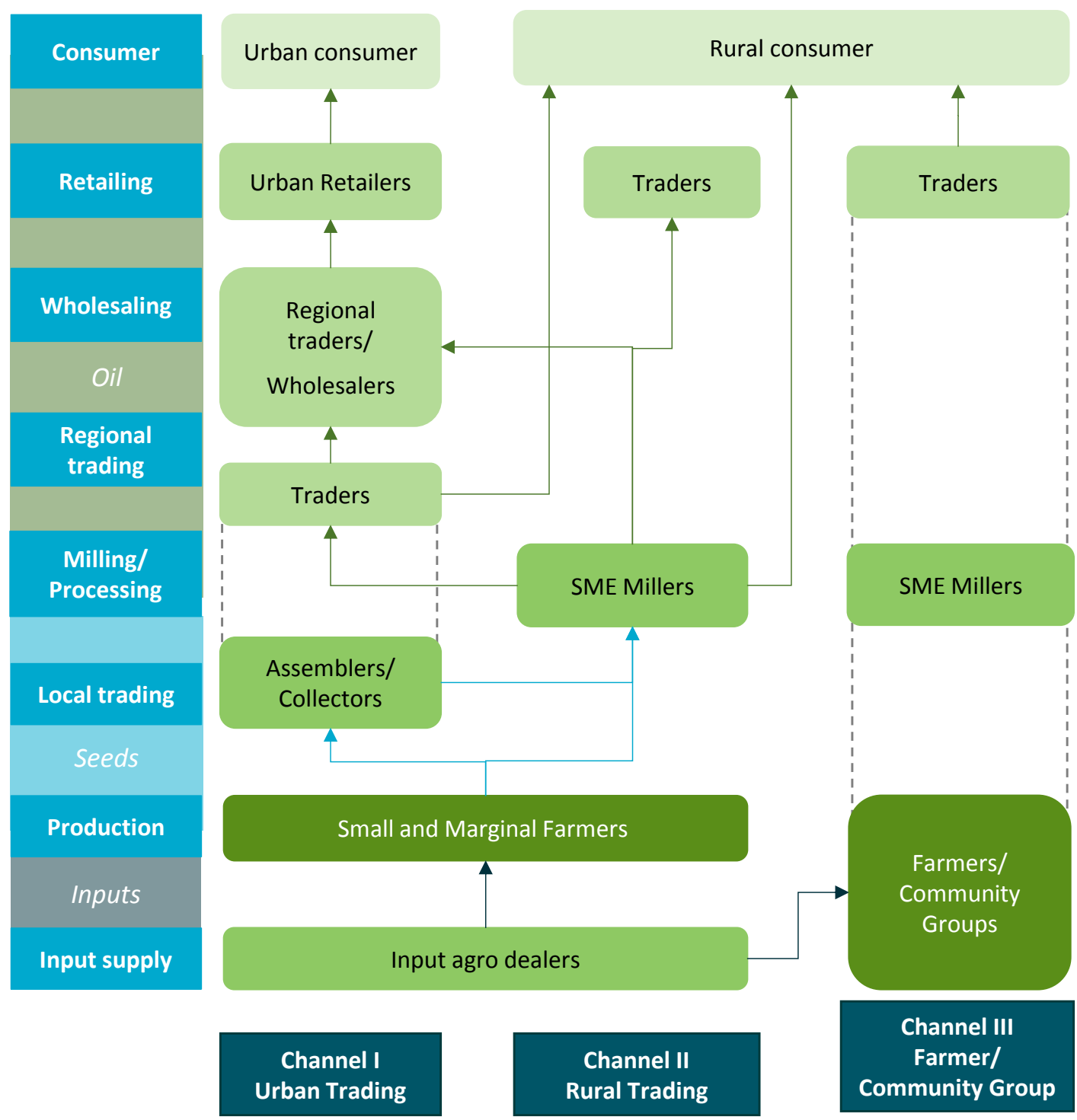

Fig. 2. Value chain map for sunflower oil in Sekendarkhali village (dotted indicated minor links)

Once the oil is produced, the owner (farmer, trader or processor) may then either sell directly to the rural market, or sell to rural retailers, and then sell to traders for movement toward the urban market. The market for sunflower oil within the regions is well established and absorbs more than $75 \%$ of the sunflower oil produced in the regions. Therefore, only a relatively small percentage is traded outside the regions. Local consumers are able to purchase sunflower oil in the following ways:

- from farmers who are paid for the processing of their crop,

- from local traders who purchased from farmers and paid for the processing

- from processors who bought either the seed or oil from the farmers

- from retailers who bought the oil from processors or traders
- from farmer/community groups who own processing equipment.

Urban consumers either obtain the oil from urban retailers, urban wholesalers/retailers or purchase the oil when making trips to the region.

The price of sunflower seeds varies between the two extremes of excess supply, and scarcity. Excess supply occurs usually during the time of harvest since all the farmers in the region harvest simultaneously. During this time the price of sunflower seeds reaches an annual low. However later in the year as the supply is consumed, and especially during the time of replanting, the price of sunflower seeds climbs to the year's highest position.

The sunflower value chain dynamics can be seen four interlinkages (Fig. 3). Production and processing are linked with low level of productivity and local level 
processing mill which is mainly traditional and mostly unexplored yet.

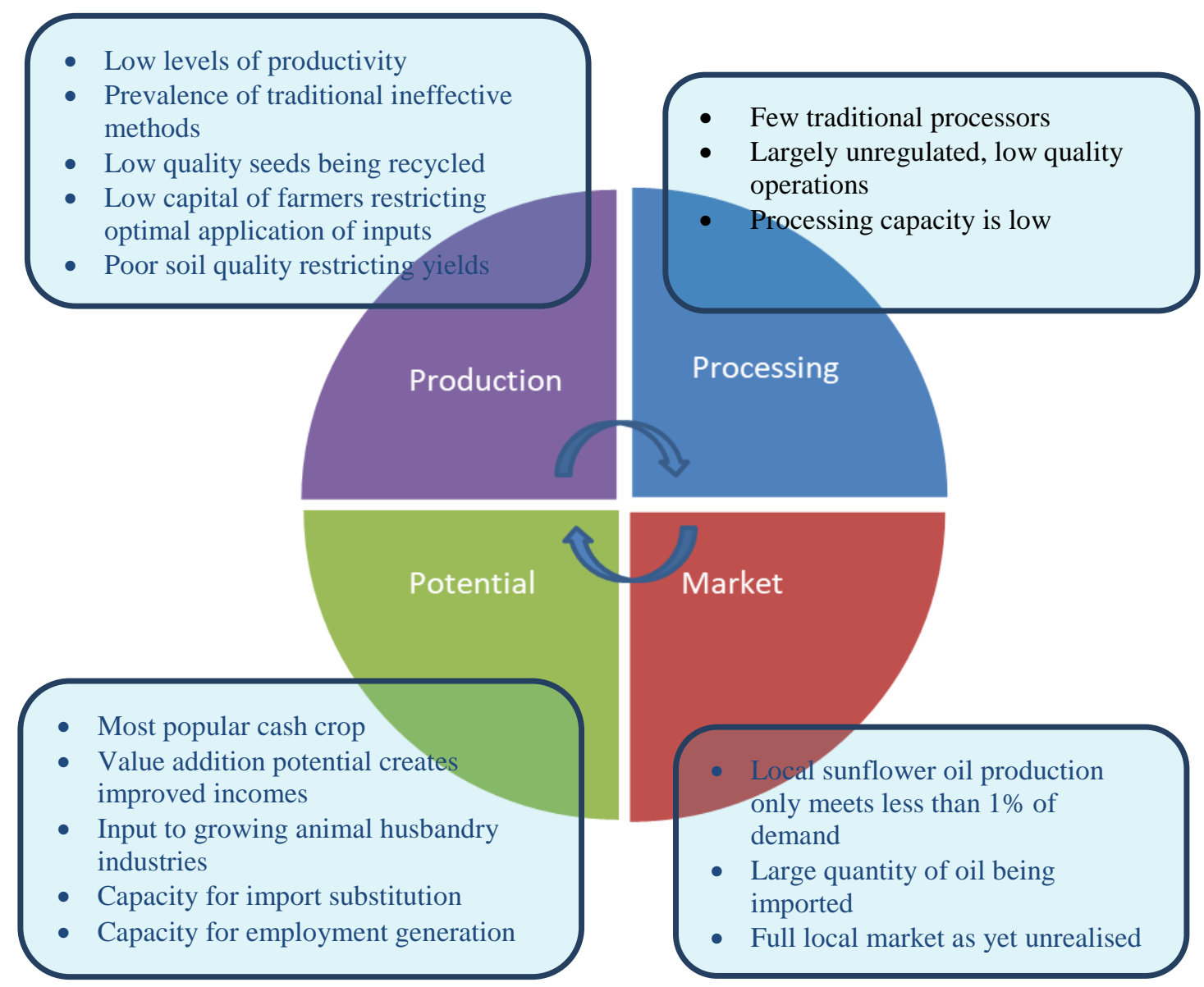

Fig. 3. The sunflower value chain dynamics

\section{Cost and revenue drivers and margins}

On an average, the total costs (production and marketing) incurred by the farmers were $\mathrm{Tk}$. 11,986.30/acre (100 decimals) of sunflower (Table 2). The costs incurred by the farmers included cost of using seed, labour, and fertilizers. On average farmers harvested $310.75 \mathrm{~kg}$ of sunflower seed per acre which much lower than the other areas (varied from $562.5 \mathrm{~kg}$ to $750 \mathrm{~kg}$ per acre). The lower yields, according to farmers, were due to stagnation of water due to excessive rainfall. Farmers used individual storage facilities to keep small quantities of sunflower after harvest in their homestead area. Most farmers indicated that they stored sunflower couple of months before sales.

Table 2. Total production cost during the season 2017-2018

\begin{tabular}{llc}
\hline Serial/no. & Activity/Input & Tk./acre \\
\hline 1. & Land preparation & 1930.95 \\
2. & Labour & 4075.76 \\
3. & Seeds & 3514.14 \\
4. & Fertilizers & 2465.45 \\
& Total cost & $11,986.30$ \\
\hline
\end{tabular}

Most of the farmers sold their produces in the farmyard. Therefore, they did not have any marketing cost for carrying the produces into the market. The gross margin at farm gate during the period of February-March 2018 was estimated to be Tk. 3551.20 which is low due to lower yield (Table 3 ). This year, farmers noticed that they did not get profit due to loss of yield that comes from heavy rainfall and water logging but they argued that they can make profit in the coming years if they received better price which they received in the last year. The market price of sunflower seed is comparatively good which was Tk. $50 / \mathrm{kg}$ and they can sell their produce in the market with the presence of local processing mills and a big processing mill. Farmers of the nearby villages can produce 562.5 to $750 \mathrm{~kg} / \mathrm{acre}$ of sunflower seed which gives Sekendarkhali village farmers the impression that it can be a profitable crop. Currently, the production of sunflower is insufficient to meet the local demand.

Table 3. Gross margin (per acre) for sunflower farmers for February-March 2018 cropping season

\begin{tabular}{llc}
\hline Sl/n & Parameters & Parameter value \\
\hline 1. & Quantity sold $(\mathrm{kg})$ & 310.75 \\
& (668.75kg/acre) & \\
2. & Selling price in Tk per kg & 50.00 \\
3. & Production cost in Tk/acre & $11,986.30$ \\
\hline
\end{tabular}


4.

$15,537.50$

Profit margin (4-3)

3551.20

Note: During the calculation, land use cost and depreciation were not taken into account as land is fallow. If we consider these, the profit margin might be change.

Assemblers received a total gross margin of Tk 588/100 $\mathrm{kg}$ of sunflower seeds (Table 4).

Table 4. Gross margin for assemblers/collectors of sunflower

\begin{tabular}{llc}
\hline S/N & Parameter & $\begin{array}{c}\text { Parameter } \\
\text { value }\end{array}$ \\
\hline 1. & Quantity of sunflower bought in kg & 100 \\
2. & Buying price in Tk Per kg & 50 \\
3. & Purchase cost $(1 * 2)$ & 5000 \\
4. & Transport costs $(\mathrm{Tk} / 100 \mathrm{~kg})$ & 200 \\
5. & Loading and unloading $(\mathrm{Tk} / 100 \mathrm{~kg})$ & 450 \\
6. & Total cost incurred $(3+4+5)$ & 5650 \\
7. & Quantity sold, kg & 100 \\
8. & Selling price $/ \mathrm{kg}$ & 55.88 \\
9. & Gross revenue $(7 * 8)$ & 5588 \\
10. & Profit margin $(9-6)$ & 588 \\
\hline
\end{tabular}

At wholesale node the total gross margin is found to be Tk. 209/100kg of sunflower seeds (Table 5). The gross margin at wholesale node was lower compared to that at assembling node.

Table 5. Gross margin for wholesalers of sunflower

\begin{tabular}{llc}
\hline S/N & Parameter & $\begin{array}{c}\text { Parameter } \\
\text { value }\end{array}$ \\
\hline 1. & Quantity of sunflower bought in $\mathrm{kg}$ & 100 \\
2. & Purchase price, Tk./kg & 55.88 \\
3. & Purchase cost $(1 * 2)$ & 5588 \\
4. & Transport costs $(\mathrm{Tk} . / 100 \mathrm{~kg})$ & 200 \\
5. & Labour charges $(\mathrm{Tk} . / 100 \mathrm{~kg})$ & 250 \\
6. & Market charges $(\mathrm{Tk} . / 100 \mathrm{~kg})$ & 75 \\
7. & Total cost incurred $(3+4+5+6)$ & 6113 \\
8. & Quantity sold in kg & 100 \\
9. & Selling price, Tk./kg & 63.22 \\
10. & Gross revenue $(8 * 9)$ & 6322 \\
11. & Profit margin $(10-7)$ & 209 \\
\hline
\end{tabular}

Note: The profit margin is calculated on the basis of variable cost.

It is observed that processor received gross margin of $100 \mathrm{~kg}$ of equivalent sunflower seed which is around $40.0 \mathrm{~kg}$ oil is Tk 878 (Table 6). This does not take into account fixed costs.

Table 6. Gross margin for processors of sunflower oil

\begin{tabular}{llc}
\hline S/N & Parameter & $\begin{array}{c}\text { Parameter } \\
\text { value }\end{array}$ \\
\hline 1 & Quantity of sunflower bought in kg & 100 \\
2 & Buying price, Tk./kg & 63.22 \\
3 & Purchase cost $(1 * 2)$ & 6322 \\
4 & Transport costs (Tk./100kg) & 250 \\
5 & Processing cost (Tk./100kg) & 700 \\
6 & Packaging cost (Tk./100kg) & 450 \\
7 & Total cost incurred (3+4+5+6) & 7722 \\
8 & Quantity sold, kg & 40 \\
9 & Selling price, Tk./liter & 215 \\
10 & Gross revenue (9*8) & 8600 \\
11 & Profit margin $(10-7)$ & 878 \\
\hline
\end{tabular}

Note: The profit margin is calculated on the basis of variable cost.

The total gross margin at the retail node was found to be Tk 450/ $100 \mathrm{~kg}$ sunflower oil (Table 7). The gross margin at retail node was found to be lower compared to that other nodes. As most of the retailers sell sunflower oil with other grocery items, they received comparatively low margin of each items.

Table 7. Gross margin for retailers of sunflower oil

\begin{tabular}{llc} 
S/N & Parameter & $\begin{array}{c}\text { Parameter } \\
\text { value }\end{array}$ \\
1. & Quantity of sunflower bought in kg & 100 \\
2. & Buying price, Tk./kg & 215 \\
3. & Purchase cost $(1 * 2)$ & 21500 \\
4. & Transport costs $(\mathrm{Tk} / 100 \mathrm{~kg})$ & 250 \\
5. & Labour $(\mathrm{Tk} / 100 \mathrm{~kg})$ & 150 \\
6. & Shop rent and others $(\mathrm{Tk} . / 100 \mathrm{~kg})$ & 125 \\
7. & Market charge $(\mathrm{Tk} . / 100 \mathrm{~kg})$ & 25 \\
8. & Total cost incurred $(3+4+5+6+7)$ & 22050 \\
9. & Quantity sold, $\mathrm{kg}$ & 100 \\
10. & Selling price, Tk./kg & 225 \\
11. & Gross revenue $(9 * 10)$ & 22500 \\
12. & Profit margin $(11-8)$ & 450 \\
\hline
\end{tabular}

Note: The profit margin is calculated on the basis of variable cost.

\section{Constraints and Opportunities}

Sunflower farmers and market actors faced constraints to cultivate and market the sunflower seed and oil. Production constraints limit the production area and reduce the yield. Marketing constraints limit the farmers and actors for receiving lower profit. The opportunities indicated the future hope that can be reached by mitigating the constraints.

\section{Constraints}

In the study areas farmer and market actors faced some constraints which prevent them to active participation in production and marketing of sunflower seed and oil. Most of the farmers reported that lack of /scarcity of improved seeds was the serious problem which forced farmers to use own seeds which were often low-yielding. Sunflower is a water sensitive crop. Due to heavy rain there are water logging in the sunflower field which results in low yields, and in some cases results in losses of the farmers. The seeds that farmers' produced sometime in low quality due to poor postharvest handling, resulting in farmers receiving lower returns from the sunflower oil production. Most of the farmers produced sunflower without adequate knowledge of production and management of sunflower filed which degraded them in low production and yield. Processing skills were lacking mainly among small and marginal farmers and processors, leading to poor quality products that are not competitive with the market preference

\section{Opportunities}

In the study area there was huge opportunity to produce sunflower as the land was fellow during the robi season. During this time farmers cannot produce other crops due to salinity. Therefore, there is an opportunity for growth of private sector entrepreneurs/farmers, through the 
supply of higher quality sunflower seeds as the demand of sunflower oil is higher compare to other edible oil. Farmers desire training on improved agronomic practices and management that allow them to optimize the usage of their land holding and enable the proper use of input supplies for improved productivity. An opportunity also exists for the introduction of systems for the training, registration and regulation of sunflower oil processors in order to standardize practices and quality standards. There is also opportunity for the training of production and processing actors in order to improve productivity reduce costs and provide a lower priced, more competitive product for the end market. Furthermore, there is huge increasing demand for sunflower oil based on growing health consciousness. Finally opportunity also exists for import substitution with the introduction of competitive local oil.

\section{Conclusion}

Sunflower as a cash crop, can significantly contribute to increase household income and food security and thus raising the standard of living of rural people. The study found that the common marketing system used involved many links with no value addition within the channels which increased the total cost by double handling. The findings revealed that $40 \%$ of the total productions were sold by farmers to chain actors in 2017/2018 cropping season while the remaining $60 \%$ was left for domestic consumption. Most of the farmers collected seeds for planting from the nearby local market from the local seed traders. Some also used the seed of their own cultivated during last season. This was because of scarcity of seeds. Farmers in the study area were in good communication with the traders specifically the collectors for selling their produce. Most of the collectors were there known person. In this case, the farmers described about the credibility of making sale with the collectors. Farmers were not engaged with the marketing activities in the study area. Thus, the whole channel mainly comprised of collectors, processors, wholesalers, retailers. Every actor in his own stream was advanced with the fact of making profit. Sunflower oil production is profitable as farmers (those who converted their seed into oil) received Tk. 225/kg. The main business challenge in sunflower production was scarcity of quality seed and the marketing challenge was fluctuation of prices.

\section{Acknowledgement}

This research has been done in line with the objectives of the "Promoting Socially Inclusive \& Sustainable Agricultural Intensification in West Bengal \& Bangladesh" project sponsored by the Australian Centre for International Agricultural Research (ACIAR), Australia.

\section{References}

ACT. 2010. Value chain analysis of sunflower for the regions of Morogoro, Iringa, Mbeya and Rukwa. Draft report. Match Maker Associates Ltd.

Bangladesh Bank. 2017. Category wise import payments, Statistics Department, Bangladesh Bank, Dhaka, Bangladesh. Retrieved 08July, 2018 from www.bb.org.bd/econdata/import/categoryimp.php

BBS. 2017. Yearbook of Agricultural Statistics, Bangladesh Bureau of Statistics. Statistics and Informatics Division (SID), Ministry of Planning, Government of the People's Republic of Bangladesh.

BBS (Bangladesh Bureau of Statistics). 2018. Statistics and Informatics Division (SID), Ministry of Planning, Government of the People's Republic of Bangladesh.

Gain Report. 2018. Bangladesh Oilseeds and Products Annual. Gain Report Number BG 1802. US Government

Habib, S. H., Kohinur, H. and Hossain, M.K. 2017. Sunflower: a new hope of Bangladesh in the context of climate change. Daily Observer, Retrieved July 07/2018.

Hossain, M.I., Afroz, S., Das, M., Haque, M.M. and Islam, M.S. 2018. Agricultural intensification at Sekendarkhali village of Amtali Upazila, Bangladesh: Market dynamics of sunflower. Report No. 5. Of the value chains market series for promoting socially inclusive and sustainable agricultural intensification in West Bengal and Bangladesh.

Kaplinsky, R. and Morris, M. 2001. A handbook for value-chain research [online]. http://www.prism.uct.ac.za/Papers/VchNov01.pdf IDRC. Retrieved: $18 / 05 / 2019$

Khatun, M., Hossain, T.M.B., Miah, M.A.M., Khandoker, S. and Rashid, M.A. 2016. Profitability of sunflower cultivation in some selected sites of Bangladesh. Bangladesh Journal of Agricultural Research, 41(4): 599-623.

Larsson, S. 2018. The sunflower value chain: a case study in Babati, Tanzania. Bachelor thesis. Sodertom University.

LGED. 2018. Map of Amtali Upazila Retrieved July 07/2018 http://www.lged.gov.bd/UploadedDocument/Map/BARISA L/barguna/amtali/amtali)

Mroto, E.H. 2015. Gender analysis in the sunflower value chain: a case of Mvomero district, Tanzania. A. M. S. dissertation. University of Agriculture. Morogoro, Tanzania.

Rahman, M.J. 2014. Profitability of sunflower cultivation in some selected sites of Bangladesh. Department of Food Science, The University of Comilla.

Shushilan. 2016. Census data collected by Shushilan, Field visit report, SIAGI project. 